\title{
CORPORATE LAW: MANDATORY OFFER REGIME IN NEED OF PRECISE EXEMPTIONS AND LEEWAY*
}

\author{
Paul Nkoane \\ BCom LLB
}

\section{SUMMARY}

Mandatory offers are generally envisioned to curb unfair and abusive conduct during and after acquisition of securities in a regulated company. The regime is designed to offer minorities an opportunity to exit the company during takeovers. Mandatory offers are formulated to regulate all acquisitions in the range of the prescribed percentage. Only where the Panel exempts an offeror will the transaction not be covered by the rules of mandatory offers. In keeping with the purpose of the Companies Act, this article is intended to indicate that clear and precise exemptions must form an integral component of this regime.

\section{$1 \quad$ INTRODUCTION}

Law reform is like a ship that moves the law forward. Similarly, clarity and certainty in law is the mainstay that steadies that ship in turbulent waters. Without reform the law stagnates, and without clearly defined rules the law can become inconstant and its application will possibly create uncertainty. One consequence of variable laws is that a rule may be extended to meet a case for which provision has clearly and undoubtedly not been made. In that regard, it is important that, when a forum interprets any rule, it should not struggle to determine the application of that rule and find itself reduced to drawing its own inferences. Thus, for the law not to be randomly varied at the instance of the trier of facts, rules need to be overtly outlined. Accordingly, a perusal of the rules should afford the reader adequate and clear information. This is more significant in corporate law, because it is a vehicle used to drive economic growth. It is accordingly important for business regulations to be clear, certain and accessible. ${ }^{2}$ The Companies Act similarly advocates for rules that are certain and predictable. ${ }^{3}$

\footnotetext{
This work is a supplement to the article titled Nkoane "Is There a Need for Mandatory Offers in Company Takeovers? A Critical Analysis" 2015 36(2) Obiter 363-386.

Engels v Allied Chemical Manufacturers (Pty) Ltd 1993 (4) SA 45 (Nm).

2 See Cassim "The Companies Act 2008: An Overview of a Few of Its Core Provisions" 2010 22 SA Merc LJ 157.
}

3 S 7(I) of the Companies Act 71 of 2008. 
The law requires that mandatory offers must be made for minority securities where an offeror intends to acquire securities in a regulated company ${ }^{4}$ in the region of the prescribed percentage. ${ }^{5}$ It is submitted that such acquisitions match an affected transaction. ${ }^{6}$ This canon affects all such acquisitions. This construction culminates into amenable rules that are far too problematic. Because of material inadequacies that result in lack of guiding exemptions, this regime can attract criticism. This is so because its rules apply to every transaction that is above the prescribed percentage ${ }^{7}$ and that involves a regulated company. This has prompted others to impugn this regime, and have called for its demise. ${ }^{8}$

Although the regime is founded on sound principles, with recent developments its basis is open to challenge. ${ }^{9}$ The control principle seems to be the most acute problem in the system of mandatory offers. The Companies Regulations provide the definition of control, which is evidently connected to the prescribed percentage. It is submitted that the acquirer of securities attains control by holding a beneficial interest in a regulated company equal to or exceeding the specified percentage of the voting rights in that regulated company. ${ }^{10}$ It is quite possible that a person may hold a beneficial interest in the range of the prescribed percentage without gaining control (whether it be de facto or effective) of a regulated company. ${ }^{11}$ In such circumstances the Panel (the Panel is an organisation that regulates affected transactions) "may" exempt the acquirer. ${ }^{12}$ Accordingly, the Panel bears the responsibility to discretionally exempt acquirers. Who in particular may be exempted is not quite clear. This article will indicate the necessity of having guiding principles to regulate mandatory offers. Thus, continuous consultations with the Panel to investigate whether a transaction falls within the scope of affected transaction should only occur in specific cases. This will enable the parties to engage in negotiations without having to forward dense and sensitive documents to the Panel, save for instance where the certificate of compliance is sought.

Equally, if a person may not be exempt for a particular reason, and it appears that it would create an economic burden to compel the acquirer to perform beyond its comforts (where the enforcement of mandatory offers could place the offeror under hardship), particularly where the acquirer poses no definite peril to the existing shareholders, leeway has to be

4 See s 118(1) of the Companies Act 71 of 2008 for the definition of "regulated company".

5 S 123(2) of the Companies Act 71 of 2011; and Delport (ed), Vorster, Burdette, Esser and Lombard Henochsberg on the Companies Act 71 of 2008 (2011) 431-433.

6 The affected transactions include mandatory offers; and s 117(1)(c)(iv) of the Companies Act 71 of 2008. Luiz correctly articulates that the definition of affected transactions focuses on the nature of the transaction rather that the effects of the transaction (the change of control); Luiz "Some Comments on the Scheme of Arrangement as an 'Affected Transaction' as Defined in the Companies Act 71 of 2008" 201215 PER 102 104-105.

7 S 123(5) of the Companies Act 71 of 2011; and R 86(1) of the Companies Regulation 2011.

8 Wiblin "Mandatory Takeover Offer - Too High a Price for the Economy to Pay?" 2004 Journal for Juridical Science 173183.

9 Company law has evolved and incorporates mechanics that have enhanced shareholder participation in company meetings; and s 60 and 61(10) of the Companies Act 71 of 2008.

$10 \mathrm{R} 81$ (e) of the Companies Regulations 2011.

11 See subheading 425 below.

$12 \mathrm{~S} 119(6)$ of the Companies Act 71 of 2008. 
provided to encourage economic activity. The Companies Act advocates for continuous investments and economic growth, ${ }^{13}$ therefore, in keeping with this ideology it is important to curb restrictive rules. This can be done by providing the offeror with impunity from making offers in particular situations, and, moreover, by encouraging minorities to agree on alternative options. Minorities would have the opportunity to participate in the restructuring of the company. In that light, possible leeway to avoid the making of mandatory offers must be proposed. The provision of leeway is important in one respect: an acquirer who would otherwise be put off by the rules, may be encouraged to invest in a regulated company, knowing that it will not be expected to invest beyond its means. This article attempts to provide apposite mechanics to supplement this regime of law.

\section{AN OVERVIEW OF THE REGIME OF MANDATORY OFFERS}

It is trite law that majority rules. This law is not an exception to corporate law. In more cases than not, the majority has the power to determine the fate of an entity. Owing to the degree of their shareholding, the majority should have the muscle to dominate; and they may at times exercise their authority overbearingly. Therefore, there is a constant need to protect those who may fall victim to the powerful. ${ }^{14}$ The courts are often hesitant to interfere in company affairs unless there is a clear breach of the common law, any relevant legislation, or where a case of blatant abuse of power is fashioned. ${ }^{15}$ Legislative measures, therefore, had to be put in place to protect minorities in abstract cases. ${ }^{16}$ The system of mandatory offers, in that light, is envisioned to protect minorities against possible abuse in takeovers. An mandatory offer rule is triggered when a person acting alone or in concert with others acquires securities within the range of the prescribed percentage. ${ }^{17}$ It is possible that during or after acquisitions, minorities could be overlooked and sometimes sidelined in respect of propositions to transform the company. ${ }^{18}$ Moreover, the minorities could fall victim to the socalled "white-collar looters" or "early-dawn raiders", who are primarily concerned with the gaining of control of the company, mainly to scavenge and loot. ${ }^{19}$ In truth, any opposition by minorities to stop the possible abuse will be of no consequence if the majority has made up its mind and is willing to implement its plan.

3 S 7 of the Companies Act 71 of 2008.

14 See Ngalwana "Majority Rule and Minority Protection in South African Company Law: A Reddish Herring" 1996113 SALJ 527.

15 Du Plessis "Revisiting the Judge-made Rule of Non-interference in Internal Company Matters" 2010127 SALJ 304.

16 Minorities are therefore protected against abusive conduct that may not necessarily warrant judicial intervention, especially so, if the abuse is conducted within the domain of the law. This kind of abuse cannot be detected during acquisitions, it manifests itself after acquisitions.

$17 \mathrm{~S} 123$ of the Companies Act 71 of 2008.

18 Haslam v Sefalana Employee Benefits Organisation [1997] 4 All SA 269 (W) 275.

19 Spinnaker Investments (Pty) Ltd v Tongaat Group Ltd 1982 (1) SA 65 (A) 72-73. 
In that respect, the regime of mandatory offers is envisaged to protect minorities during takeovers of regulated companies. ${ }^{20}$ Only minorities in regulated companies are afforded protection during takeovers. Regulated companies include a public or listed company, a state-owned company (unless exempt in terms of the Act) and specific private companies. ${ }^{21} \mathrm{~A}$ person must acquire a stake in a regulated company, which acquisition must result in an affected transaction; that acquisition will automatically trigger mandatory offer rules. The law, therefore, considers mandatory offers to fall in the sphere of affected transactions. ${ }^{22}$ It follows then that mandatory offers are triggered where acquisition of securities above the threshold figure results in an affected transaction. Thus, acquisitions of non-ordinary and non-voting securities, like preference shares, will not fall under the scope of an affected transaction and the obligation to make mandatory offers will not arise where a party has acquired such preference shares above the prescribed percentage. ${ }^{23}$

Where there is a pact among friends or relatives (forming a group) and their aim is to acquire a stake above the prescribed percentage in a regulated company, and the group succeeds in acquiring that stake, the group has to make offers to minorities, despite the fact that each member of the group holds a percentage below the prescribed percentage. ${ }^{24}$ Therefore, it makes little difference whether a person acts alone or in concert with others, as long as the parties have exceeded the prescribed percentage (which is set at $35 \%$ ) by law, an obligation arises for the parties to make mandatory offers for minority securities. ${ }^{25}$ Before acquisition, the parties must be able to exercise less than the prescribed percentage of all the voting rights attached to securities of that company only. After acquisition, the parties must be able to exercise at least the prescribed percentage of all the voting rights attached to securities of that company. ${ }^{26}$ This means that a person or persons acting in concert must - before the acquisition - hold a stock of securities below the threshold (the prescribed percentage) or owned no stock of securities in the target company, and as a result of the acquisition, the person or persons must be able to exercise control over securities above the prescribed percentage. It is deemed that, by virtue of acquiring securities in the range of the prescribed percentage, the person or persons acting in concert may be able to gain control of the target company. ${ }^{27}$

The notion that the acquisition of the prescribed percentage should represent control is based on the premise that a party may exercise control without gaining securities over the $50 \%$ of all voting rights. ${ }^{28}$ This kind of control is referred to as effective control. Thus, where a party acquires

S 123 of the Companies Act 71 of 2008.

S 118(1) of the Companies Act 71 of 2008.

S 117(1)(c) of the Companies Act 71 of 2008.

$23 \mathrm{R}$ 86(3) of the Companies Regulations 2011. Also see Delport et al Henochsberg on the Companies Act 71 of 2008433 .

24 S 117(1)(b), s 117(2), s 118(5) and s 123(2)(a)(ii) of the Companies Act 71 of 2008.

25 Securities Regulation Panel v MGX Holdings Ltd 2004 CLR 444 (W) 467.

26 S 123(2)(b) of the Companies Act 71 of 2008.

27 See rule 8.1 of the Securities Regulation Code on Takeovers and Mergers (the Code).

28 See Luiz "Mandatory Offers" 2000 SA Merc LJ 382. 
securities in the region of the prescribed percentage, it is purported that the party may have gained control of the company, and therefore minorities ought to be protected. ${ }^{29}$ In this regard, it is important that a distinction should be drawn between control de facto and effective control. On the one hand, control de facto represents real control of a company in general meetings, while on the other hand effective control represent ostensible control. It is, therefore, required that, when a person or persons gain effective control as framed in the takeover regulations, the person or persons must inform the Panel and the affected parties within the stipulated time. Thereafter, mandatory offer bids must be launched. ${ }^{30}$

\section{DE FACTO CONTROL AND EFFECTIVE CONTROL}

It is important to understand the theories of control generally associated with takeovers. This will enable us to appreciate the dangers which may arise with acquisitions of a certain percentage of securities of a regulated company. The understanding of the theories of control will enable us to come to an informed opinion about which acquisition has the potential to imperil the rights and interests of minorities. This, in turn, may assist us in drawing conclusions about which acquisitions may endanger minority interest.

\section{What the meaning of de facto control entails}

Control can be generally defined as the power that a person or persons may exercise to determine the direction or fate of the company. There are two types of real control that must be distinguished and that may be exercised in moving the company forward: the control exercised by management and the control that is exercised by shareholders. ${ }^{31}$ Management generally exercises control with regard to the day-to-day running of the company; thus their decision-making and skill or lack of these, can result in huge profits or substantial losses. Therefore, the control exercised by management is fundamental in creating or sustaining financial success of a company. The control that management exercises is nevertheless subordinate to the ultimate control, commonly used to determine the fate of the company. ${ }^{32}$ This type of control is conferred on the shareholders. Thus, ultimate control over a company's affairs is exercised by its shareholders in a general meeting. The influence to determine the outcome in general meetings is, therefore, referred to as de jure authority over a company in the sense of having power to control a company's destiny. ${ }^{33}$ As such, the acquisition of majority shares in a company would result in acquiring control of the company, not merely in acquiring a financial interest in the business of that

\footnotetext{
See Explanatory notes 1 (a) of the Code.

S 123(3) and (4) of the Companies Act 71 of 2008.

East Cross Sea Transport Inc v Elgin Brown \& Hamer (Pty) Ltd 1992(1) SA 102 (D) 107.

East Cross Sea Transport Inc v Elgin Brown \& Hamer (Pty) Ltd supra.

Belfry Marine Ltd v Palm Base Maritime SDN BIM-D [1999] 3 All SA 337 (A) 346.
} 
company. ${ }^{34}$ Thus, control in relation to a company is defined as meaning, inter alia, "a majority of its shares".

The pivotal definition of control de facto is provided in the Companies Act. $^{36}$ It is submitted that a person controls a juristic person, or its business, if that person, together with any related or interrelated person, is directly or indirectly able to exercise or control the exercise of a majority of the voting rights associated with securities of that company. ${ }^{37}$ Moreover, a person has control, if that person, together with any related or interrelated person, directly or indirectly has the right to appoint or elect, or control the appointment or election of, directors of that company who control a majority of the votes at a meeting of the board. ${ }^{38}$ The phrase "control of the majority of the voting rights" is intended to imply that all shareholders must be present in the meeting, or all shareholders must be able to exercise their vote at that particular juncture. It is overt that under such circumstances the decisive majority would be $50 \%$ plus one more vote of all the voting rights of the company voting in favour of the tabled resolution. It is submitted that this definition should be read to coincide with the definition of "general voting rights", contained in section 1 of the Act. ${ }^{39}$ This is an ordinary definition of control of a company under circumstances where all shareholders are present at the meetings. This somewhat implies that in a policy sense the meaning of control should not be understood under such circumstance only. This is where the understanding of the term "effective control" illustrates that control of a company can extend beyond its ordinary meaning.

\section{Effective control}

The theory of effective control is founded on the premises that a shareholder is able to exercise control even where the shareholder owns a lower percentage of securities than the percentage commonly associated with ordinary control. In that light, the acquirer does not have to gain control de facto. Therefore, control over a company can be exercised even without a majority shareholding. ${ }^{40}$ This theory originated in England. ${ }^{41}$ The English realised that a company could be controlled and its destiny determined by a shareholder or shareholders acting in concert who mathematically do not carry majority votes under circumstances where all shareholders are present in the meeting. ${ }^{42}$ This can seemingly happen in cases where the shareholding of the company is scattered. ${ }^{43}$ In such cases, the shareholder or shareholders with enough securities, are able to adopt resolutions without

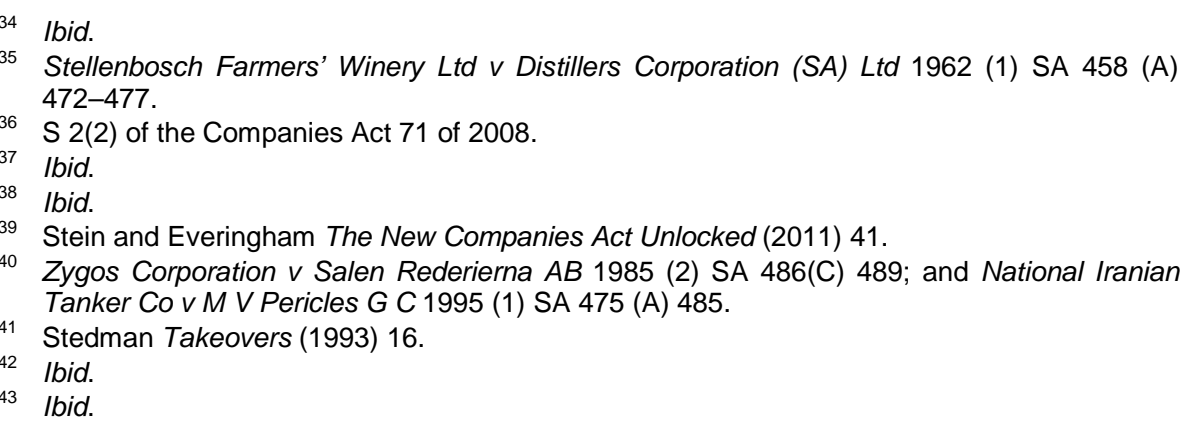


significant opposition. ${ }^{44}$ Hence the term "effective" control. The South African legislator took cognisance of the theory of effective control, and regarded a person or persons who obtained the prescribed percentage as capable of exercising effective control in cases where the shareholding of the company is widespread. ${ }^{45}$ This is so, because the Companies Act stipulates that a quorum can be constituted by $25 \%$ of the shareholders, ${ }^{46}$ and within this $25 \%$, a shareholder acting alone, or in concert with others, is able to pass a resolution that could disenfranchise minorities. This is the premise that underlies the regime of mandatory offers, to be precise, the prescribed percentage. ${ }^{47}$ Thus, the trigger for mandatory offers is based on the theory of the gaining of effective control. For that reason, if the acquirer of securities gains control in terms of the takeover rules, the acquirer thereupon carries the responsibility to make offers for minority securities. ${ }^{48}$ The mere fact that the acquirer has obtained securities in the range of the specified percentage ( $35 \%$ of securities of a regulated company) will mean that the acquirer is capable of exercising control in terms of takeovers.

Conversely, company law has evolved, and although the regime of mandatory offers has somewhat followed the trend, there are noticeable stagnations. For instance, the Companies Act has introduced a provision intended to improve shareholder participation in the adoption of resolutions, ${ }^{49}$ but there is no adjustment to the rules of mandatory offers in relation to this development. This provision has effectively put holes in the philosophy of effective control, because even the far located shareholders can be able to exercise their votes without having to attend meetings. Conventional wisdom has it that the rules of mandatory offers have to be adjusted to coincide with this development. Thus, the Minister and the Panel should introduce provisions on exemptions and leeway to supplement this progress.

\section{Where the intention to gain control is lacking}

It is obvious that not all offerors are motivated by the gaining of control. ${ }^{50}$ Lawmakers in other jurisdictions have recognised this and have provided defined exemptions in their takeover rules. Australia is one such jurisdiction, as the theory of effective control is recognised in that regime. Nevertheless, the Australian legislator found it necessary to provide exemptions projected at easing restrictions imposed by the basic prohibitions on acquisition rules. ${ }^{51}$ The exemptions are clearly outlined; moreover, the Australian takeover authority is provided with the discretionary power to further exempt

44 Ibid.

45 Rule 8.1 of the Code.

$46 \mathrm{~S} 64$ of the Companies Act 71 of 2008.

47 See explanatory notes $1(\mathrm{a})$ of Securities Regulation Code on Takeovers and Mergers (the Code).

48 S 123 of the Companies Act 71 of 2008.

49 S 60 and s 61(10) of the Companies Act 71 of 2008.

50 For instance, intermediaries who deal in financial instruments as sources of generating income do not generally concern themselves with gaining control of the company primarily to steer the company in a different direction.

51 Ford, Austin and Ramsay Ford's Principles of Corporations Law 12ed (2004) 1118-1128. 
certain acquisitions under unique circumstances. ${ }^{52}$ Although in Australia there is practically no mandatory offer system, the acquisition of securities in listed companies, or companies with more than 50 shareholders, is regulated by barring acquisition of company securities above the stipulated percentage, which is $20 \%$ of all voting securities of the company. ${ }^{53}$ Thus, where an acquirer intends to acquire securities above the stipulated percentage, the acquirer must use exemptions or leeway. ${ }^{54}$ The Australian legislator submits that, in situations where control of the company is sought and it will be attained, the acquirer is obliged to treat all shareholders equally and fairly. ${ }^{55}$ This will involve the making of offers for minority securities.

The Germans also found it necessary to provide exemptions to certain acquisitions. ${ }^{56}$ Although the Germans' provisions on exemptions are not as exhaustive as those of the Australians, they nevertheless provide adequate insight regarding which acquisitions generally do not pose a real threat to minorities. In that regard, an acquisition which falls under one of the categories of exemptions will not be covered by mandatory offer rules. Thus, an offeror who is exempt from making mandatory offers does not have to consult the German Panel - the Federal Financial Supervisory Authority (BaFin), as the rules afford the offeror adequate information.

It is, therefore, important for our law to recognise cases where control of the company may not be sought, and where the acquirer is more interested in economic gains than the controlling of the company. Similarly, the acquirer could attain the stipulated percentage of securities without being a threat to the remaining shareholders, which means the acquirer may not gain effective control even when the acquisition of securities is above the stipulated percentage. ${ }^{57}$ Even in cases where effective control is gained, but it appears that the business of the acquirer prevents it from exercising control, and the acquired securities will be sold in the near future, the mandatory offer rule should not be triggered. ${ }^{58}$ In such circumstances it would be unfair to compel the offeror to make offers to minorities because the mischief which this regime intends to prevent would be absent. The Australians and the Germans have rectified this hindrance by exempting certain acquisitions from the takeover rules. In that respect, it is judicious for the South African legislator to consider this trend.

\footnotetext{
S 611 of the Corporations Act 2001.

S 604 of the Corporations Act 2001.

54 Boardman "A Critical Analysis of the New South African Takeover Laws as Proposed under the Companies Act 71 of 2008" in Mongalo Modern Company Law for a Competitive South African Economy (2010) 325

56 See s 36 and s 37 of the Wertpapiererwerbs- und Übernahmegesetz (hereinafter "WpÜG"). In English this statute is referred to as Securities Acquisition and Takeover Act, a copy of the English version www.bafin.de/gesetze/wpueg_en.htm.

57 See subheading 425 below.

58 See subheading 421 below.
}

55 Ibid. 


\section{$4 \quad$ EXEMPTIONS}

\section{Current exemption provisions}

The Companies Act contains provisions on exemptions of affected transactions. ${ }^{59}$ It must be borne in mind that the provisions on exemptions are intended to apply to all affected transactions. ${ }^{60}$ It stands to reason that these provisions are envisioned to apply to mandatory offers, compulsory acquisitions, scheme of arrangement, amalgamation or merger, disposal of all or the greater part of the assets, or undertaking of a regulated company and acquisitions, or disposals and acquisitions in terms of section 122. As such, these provisions are not specifically formulated for mandatory offers.

It is submitted that the Panel may exempt the offeror from complying with the rules of an affected transaction if "there is no reasonable potential of the affected transaction prejudicing the interests of any existing holder of a regulated company's securities". ${ }^{.1}$ The basis of the rules that underlie the making of mandatory offers hinges on whether control of the company has changed. ${ }^{62}$ Thus, protection to minorities is only afforded if a change of control has taken place. ${ }^{63}$ It seems this rule is envisioned for situations where the offeror has acquired securities equal to or above the prescribed percentage, but will be unable to exercise effective control. In this instance the acquirer of securities has no potential to imperil the interests and the rights of existing shareholders. It is imprecise how danger will be assessed; presumably, that will depend on a case-to-case basis. Thus, it is unclear at this point which offeror in particular will be exempt in this regard, as that will have to be decided by the Panel. It appears that supplementary guidelines should be added to this regime, and can help settle this uncertainty.

Secondly, the Panel may exempt the offeror from making mandatory offers if the cost of compliance is disproportionate in relation to the value of the affected transaction. ${ }^{64}$ What is implied here is quite peculiar in terms of mandatory offers. It is not clear what the term "cost of compliance" is meant to imply. Does it mean the amount that will have to be used to fulfil an affected transaction, or does it mean preparatory cost relating to the affected transaction? If the latter is implied, this exemption is clearly irrelevant to mandatory offers. Generally, the cost of complying with mandatory offers will be far greater than preparatory cost.

Finally, the Panel may exempt the offeror from making mandatory offers if doing so is otherwise reasonable and justifiable in the circumstances, having regard to the principles and purposes of the Takeover Regulations. ${ }^{65}$ It is fairly hard to predict on what grounds the Panel will exempt an offeror, because the words used here imply that an exemption will depend entirely

9 S 119(6) of the Companies Act 71 of 2008. See further Cassim FHI (man ed), Cassim MF, Cassim R, Jooste, Shev and Yeats Contemporary Company Law 2ed (2012) 15.5.6.

S 117 of the Companies Act 71 of 2008.

$61 \mathrm{~S} 119(6)(\mathrm{a})$ of the Companies Act 71 of 2008.

62 S 123 of the Companies Act 71 of 2008.

63 Sefalana Employee Benefits Organisation v Haslam 2000 (2) SA 415 (SCA).

$64 \mathrm{~S} 119(6)(\mathrm{b})$ of the Companies Act 71 of 2008.

$65 \mathrm{~S} 119(6)(\mathrm{c})$ of the Companies Act 71 of 2008. 
on the discretion of the Panel, guided by the takeover rules, which do not provide much insight either.

\section{Proposed exemptions}

One of the drawbacks of the absence of clearly defined exemptions is that parties may have to engage in litigation to determine whether the obligation to make mandatory offers has arisen. This problem is compounded by the obvious cost of legal consultation. This would make acquisitions very costly, which is one of the pitfalls of mandatory offers, pointed out by the Department of Trade and Industry in earlier years. ${ }^{66}$ In that respect, writers suggest that perhaps the lawmakers should adopt exemptions from other jurisdictions. ${ }^{67}$ Some have hitherto suggested that a specific group should be exempted and the prescribed threshold lowered. ${ }^{68}$ Equally, it will be in the interest of the South African economy that the lawmakers formulate exemptions that should be compatible with the purpose of the Companies Act. Thus, it is important that the mischief the mandatory offer rule is intended to curtail is not overly extended to deal with cases where effective or de facto control will not be gained even where the prescribed percentage is attained. Or even in cases where control is gained, but it appears that it would not be legally suitable to enforce mandatory offers, exemptions must be provided. It is, therefore, important to exempt acquisitions that are not framed to gain control of the regulated company, and those that may not, imperil the rights of existing security holders.

\section{Intermediaries}

Security traders who are mainly concerned with procuring financial rewards should be exempt from making offers because theirs are to make financial gains only and are not necessarily concerned with the controlling of the entity. In many cases, a financial institution may collect capital from different clients and devote the capital so collected to a regulated company mainly for revenue purposes. ${ }^{69}$ These financial institutions are often referred to as intermediaries and generally conduct investments on behalf of others. ${ }^{70}$ On numerous occasions the financial institution may not be able to exercise the right to vote, as this right would be vested in others (clients). ${ }^{71}$ Only where the financial institution acquires securities in its own capacity and does not act as a market-maker (market-maker is a party that buys securities to sell them later) or a broker, it should conform to the takeover rules. Conversely, where the financial institution acts as an agent for the investor, the financial

66 Larkin and Boltar "Company Law (Including Close Corporations)" 1997 Annual Survey of South African law 403431.

67 Luiz and Van der Linde "The Mandatory Offer Obligation and Intermediaries" 2011 TSAR 113 124-125.

68 Lepaku "Mandatory Offers and BEE" 200513 Juta's Business Law 170.

69 Rosen "Financial Intermediaries as Principals and Agents" 2013 (48) Wake Forest LR 25 28-29.

70 Connolly "Legitimizing Private Placement Broker-dealer Who Deal with Private Investment Funds: A Proposal for a New Regulatory Regime and a Limited Exception to Registration" 2007 John Marshall LR 703704.

71 Luiz and Van der Linde 2011 TSAR 117. 
institution would dearth the aspiration or capacity to attain control of the offeree company.

In Pinnacle Consortium, Gardener Ross and Norman Bosman v Nedbank and Syfrets case, the Panel had to make a ruling on whether intermediaries had an obligation to make offers for minority securities should an acquisition of securities be above the stipulated threshold. ${ }^{72}$ The Panel ruled that intermediaries that do not have the intention to acquire control of the offeree company should be exempt. Although some assert that the ruling was correct, they maintain that the basis of the ruling is flawed. ${ }^{73}$ If the financial institution acts as a market-maker, the financial institution must not have any intentions to exercise votes on the securities and must dispose of the securities in the immediate future. ${ }^{74}$ By doing this, the financial institution would have shown that it has no plans to control the offeree company. It is quite clear that, if there had been exemption rules formulated to cover intermediaries, many of which do not endeavour to acquire control of a target company, there would not have been a complaint against Nedbank and Syfrets. The complainants and the defendants in that case would have saved time and money used to prosecute or defend.

It must be noted that when an intermediary acquires securities of an offeree company it is not targeting specific sellers. ${ }^{75}$ In others words, the intermediary can acquire securities of any willing seller; thus it cannot be accused of unfair practice as would be the case if it focused on specific sellers. It would, therefore, be the duty of the board to ensure that, when intermediaries approach offeree companies to acquire securities, minorities are given first preference. ${ }^{76}$ This will secure protection of minorities, and thus the intermediary will conduct its business without accusations of unfair treatment. Where the intermediary insists on acquiring securities from approached specific sellers it opens itself to allegations of biased dealings, and subsequently to the takeover rules. To suggest that intermediaries must make offers in all of its acquisitions would surely oppose the commercial nous of this industry.

\section{Dispositions among relatives}

The term "disposition" in this instance includes bequests, heirlooms or gratuitous disposition among spouses or relatives. It is submitted that securities received as inheritance parallels acquisition. ${ }^{77}$ In that respect, a

72 See Pinnacle Consortium, Gardener Ross and Norman Bosman v Nedbank and Syfrets: delivered on 16 August 2010 http://www.srpanel.co.za/Ruling\%20-\%20Nedbank\%20\%20Pinnacle.pdf.

73 Luiz and Van der Linde 2011 TSAR 113. The commentators, although endorsing the ruling they assert that the Panel ought to maintain discretionary power in these instances.

74 Pinnacle Consortium, Gardener Ross and Norman Bosman v Nedbank and Syfrets par 8.46.

75 Anonymous "Flows Through Financial Intermediaries" 1964 Federal Reserve Bulletin 549 555.

$76 \mathrm{R}$ 99(1) of the Companies Regulations 2011.

77 Delport et al Henochsberg on the Companies Act 71 of 2008 424(6): The Legislature clearly intends that for purposes of the application of this definition (of acquisition) the manner in which the ownership of the securities is obtained is to be immaterial. Thus, such means may be contractual (whatever the nature of the contract) or otherwise, eg by way of inheritance. 
discourse on succession law (testate or even intestate) in terms of dispositions is in order. In many cases the results of dispositions made in terms of gifts or inheritance may have the same repercussions with regard to takeovers. Thus, a brief discussion of the succession law will cover all pressing issues. To begin, one may ask whether the heir should be compelled to make mandatory offers because of the clear change of control brought about by inheritance. It is correct to aver that an heir may have a different vision about what is to become of the company, and in implementing mechanics to realize that vision, the heir may undoubtedly imperil the interests and the rights of minorities. Equally, if the testator planned to transform the company, and such information was communicated to the heir and the heir was acting upon those instructions, should mandatory offers be made ${ }^{78}$ The mischief which the takeover rules intend to curtail will be present here. In that respect, should the law compel the heir to make mandatory offers under such situations? If that should be the case, will that not defeat the laws of succession ${ }^{79}$ The takeover rules are possibly going to impose an onerous obligation on the heir which the testator might not have intended to occur. ${ }^{80}$ If there should be an obligation for the making of mandatory offers in such dispositions, that could create a legal quandary. The point here is that the law of succession vests rights in the heir which the takeover rules are probably going to encumber with obligations unforeseen by the testator. ${ }^{81}$ On the other hand, if the heir intends to continue the same trend as the testator, where the aim is to allow things to remain as they were, would it be compatible to takeover rules to compel the heir to make offers for minority securities? Although, there is a clear change of control at this juncture, the mischief the takeover rules intend to inhibit is absent. Perhaps the Panel should determine which heir should make offers for minority securities in such situations. Conversely, it could be problematic for the Panel to determine the intentions of the heir, in that the intentions of the heir could be kept confidential because they are in actual fact a private matter.

It is important to exempt the receiver of a gift or an heir from making offers in situations where the securities are received as gifts or inheritance. To assume that the heir may imperil the interest of minorities could be rather fatalistic. Consequently, it cannot be decisively concluded that the heir or the recipient of a gift could threaten the interest of minorities in all cases. Moreover, it would be no more than pedantic to argue that securities acquired in terms of gifts or inheritance could be equated to the practice of unfair treatment. Where there was no approach to fulfil an act (acquisition of securities) there can never be discrimination or the ostracising of others. It would invite confusion and it might be legally specious to suggest that omission to acquire minority securities where there never had been an approach to trade in securities, parallels unfair treatment. In that light, it is

78 Ex Parte McClung [1983] 2 All SA 223 (O); Ex parte Loewenthal 1939 TPD 250; and Ex parte Kruger 1976 (1) SA 609 (O).

79 See Cuming v Cuming 1945 AD 201 213; Executors Estate Fatha Mahomed v Moosa 1946 NPD 516; and Ex parte Marais 1953 (4) SA 620 (T), where to court was unwilling to suspend a bequeathed benefit.

80 Ex Parte Terwin (1908) 25 SC 890; Jewish Colonial Trust Ltd v Estate Nathan 140 AD 163; and Smith v Estate Smith 1949 (1) SA 534 (A).

81 Cooper $v$ Boyes NO 1994 (4) SA 521 (C). 
important to treat the heir the same as the testator, even though the parties are different and may have different objectives about the company. To compel the heir or the recipient of a gift to acquire minority securities will have obvious impediments for the law of succession or frustrate legitimate transfer of property between spouses. ${ }^{82}$ In many cases, there will be only a transfer of a portion of share stock from one party to another and that will not affect overall share capital of a company. The rights and responsibilities of minorities remain the same under succession and gratuitous disposition among relatives. Although as stated there is a change of control, this kind of change does not necessarily merit the move to protect minorities. Only under obvious and exceptional cases should the authorities force the heir or recipient of a gift to make offers for minority securities. This should be the case if the recipient or the heir has made his/her intentions clear that he/she will transform the company, and that transformation is possibly going to disenfranchise the minorities. Any affected party may inform the Panel, which in turn should put measures in place that will protect minorities.

\section{Acquisitions during business rescue}

It is very possible that, during business rescue finance may be sought to revive the entity in distress. Capital could be sought from external parties to finance the undertaking. It would be nonsensical to put a burden through the enforcement of mandatory offer rules on a party that is willing to invest in an entity in distress. In a true sense the purpose of business rescue is to protect the interest of shareholders and affected parties (this includes creditors and employees). ${ }^{83}$ This implies that, when the rescue mission is commenced, shareholders would have been in a difficult position, accordingly, in keeping with the purpose of business rescue, which is to relieve that difficulty, acquisitions of securities during the rescue must be unencumbered. ${ }^{84}$ In many cases, any investments coming from outside of the company may relieve the burden on the existing security holders. Enforcing the takeover regulations during business rescue, particularly mandatory offers, would defeat the sole rationale and the entire ideology of business rescue. ${ }^{85}$ It would also not make sense to put a limit on the percentage of securities which may be acquired during the rescue. It is possible that a party may want to acquire $40 \%$ of securities, and for the sake of continuing business activities, the party may desire to invest the remaining capital in the company. Thus, the acquirer may want to acquire inventory or stock required for business with its surplus. It would undoubtedly create unnecessary trouble if mandatory offer rules were enforced under such situations. It stands to reason that the enforcement of mandatory offers may possibly collide with the object and the purpose of rehabilitating an entity in distress. It is also inaccurate to suggest that the acquirer might loot from the company after acquisition because business rescue automatically restricts any

82 Finger $v$ Secretary for Inland Revenue 1971 (2) SA 411 (W); and Avis v Verseput 1943 AD 331353.

$83 \mathrm{~S} 128(1)(\mathrm{a})$ and (b) of the Companies Act 71 of 2008.

84 S 128(1)(b)(iii) of the Companies Act 71 of 2008.

85 Delport et al Henochsberg on the Companies Act 71 of 2008 424(5): An "affected transaction" are transactions listed in the Act but excludes a business rescue transaction. 
disposition of property without the practitioner's consent. ${ }^{86}$ It is also incorrect to suggest that the acquirer might loot from the company after it has been successfully rescued. If we consider that the company could have been illiquid and possibly insolvent, it is likely that most of the collected finance would have to be used to settle debts, and as such little will be left for any looting. Furthermore, agreements could be concluded with creditors, and repayments of debts may be restructured. In this instance, naturally, creditors will accrue a right for their debts to be settled before any declaration of distributions (including dividends) to shareholders. Thus, any sale of the company's property may not result in the looter gaining an advantage.

\section{Control gained after a scheme of arrangement}

Where a company repurchases its shares from one of its shareholders, it is possible that control of the company could be gained by any of the remaining shareholders. ${ }^{87}$ Depending on what gave rise to the repurchase, it could be unfair to enforce mandatory offers on the shareholder who, after the repurchase, gains control of the company. Unless the scheme of arrangement ${ }^{88}$ was employed to disenfranchise others or to gain control, it will be inapt to enforce mandatory offers. ${ }^{89}$ It is possible that shareholders may unanimously decide (this is what would happen because fundamental transactions must be adopted by special resolutions) that the company should repurchase securities from a troublesome shareholder who also wants out of the company. ${ }^{90}$ In this situation it will be unfair for the minorities to enforce mandatory offers where one of the shareholders has gained control after a transaction the minorities have sanctioned and assented to. It must be kept in mind that an independent expert must be attained to advise the company about the effects of the scheme of arrangement. ${ }^{91}$ In that respect, minorities would have been aware that one shareholder may gain control. If the minorities vote in favour of the proposed repurchase, the minorities cannot demand that the shareholder, whom they have agreed to should gain control, must make an offer for their securities, unless, if minorities had a prior agreement with the party who was going to gain control after a scheme of arrangement.

\section{Acquisitions where control is not attained}

The understanding of the term de facto control and effective control can assist us to understand the foundation mandatory offer rules are based on.

86 S 134 of the Companies Act 71 of 2008.

87 S 114 of the Companies Act 71 of 2008, in this section it is implied that the company may rearrange its capital structure, which may result in one of the security holders gaining control of the company.

88 Luiz provides a study of the scheme of arrangement in relation to the current Companies Act; and see Luiz 201215 PER 102.

89 Luiz "Using the Scheme of Arrangement to Eliminate Minority Shareholders" 201022 SA Merc LJ 443-452; and Van der Linde "Share Repurchases and the Protection of Shareholders" 2010 TSAR 288289.

$90 \mathrm{~S} 114$ and S 115 of the Companies Act 71 of 2008.

$91 \mathrm{~S} 114(2)$ and (3) of the Companies Act 71 of 2008. 
As already stated in paragraph 32 above, a mandatory offers regime is underlined by the notion of effective control. Thus, the acquirer does not have to gain control de facto to actually exercise control of a company. In some cases, where the acquirer attains the prescribed percentage (and effective control), it is possible that the interest of minorities may be in jeopardy. By the same token, the acquirer may attain securities above the prescribed percentage without gaining any control of the company. Conversely, the minority interests in the company would not be in jeopardy. Where control is not gained, even with the acquisition of securities above the prescribed percentage, the mischief the mandatory offer rule is supposed to avert would be absent. It follows that only after effective or de facto control is gained should the obligation to acquire minority securities be triggered. Where control is not gained, the Panel might exempt the offeror from complying with the takeover rules. At this point, it is not quite clear who in particular will be exempt. In that regard, this proposed exemption is intended to provide clarity.

Section 119(6)(a) and (c) of the Companies Act empowers the Panel to exempt certain acquisitions from the rules of affected transactions. This proposed exemption should, therefore, be read in conjunction with that section. Section 119(6)(a) stipulates that an offeror may be exempt if there is no reasonable potential of the affected transaction prejudicing the interests of any existing security holder. In the same vein, section 119(6)(c) stipulates that an offeror might be exempt if doing so, is otherwise reasonable and justifiable in the circumstances having regard to the principles and purposes of the Takeover Regulations.

It is rational to suggest that, where a third person holds a percentage higher than the percentage the offeror has attained, the person who might actually exercise effective control is the third, since the third party's share capital is higher than the offeror's. It is also possible that both parties may be unable to exercise effective control individually, unless acting in concert. In such a situation the affected transaction has no reasonable potential to prejudice the interests of minorities. The offeror must, therefore, be exempt from complying with the takeover rules.

It is obvious that in certain cases a third party (alone or in concert with others) could hold securities above the figure of $50 \%$ of all of the voting securities of the offeree company. This third party would exercise de facto control of the company. It is overt in this situation that, even if the offeror attains securities above the prescribed percentage, the offeror could not exercise effective control; therefore, the mischief the regime intends to curtail would be lacking in this instance. In this respect, the offeror must be exempt because doing so is otherwise reasonable and justifiable in the circumstances, having regard to the principles and purposes of mandatory offers.

Where two or more security holders reside fairly close to the company's headquarters, and their combined securities are above $50 \%$ of all of the voting securities of the offeree company, and moreover the company minutes indicate that these security holders are active participants in company affairs, it is unlikely that effective control will be exercised by the offeror. The offeror who acquires securities above the prescribed percentage 
in this situation should be exempt from the rules of mandatory offers in terms of both section 119(6)(a) and section 119(6)(c).

Where a company has a proved record of conducting shareholder meetings by other means, and has successfully adopted resolutions in that vein, it would seem that minorities may not be at peril where acquisitions are in the range of prescribed percentage. ${ }^{92}$ This would be the case where securities holders participate adequately in such arrangements and in that regard an offeror would be unable to exercise effective control. It might be argued that perhaps the issue of unfair treatment is acute in this instance. However, the theory of unfair treatment overlaps with the gaining of control. In other words, it would be illogical to argue that any acquisition above the prescribed percentage where control is not gained, amounts to unfair treatment if the minority's securities are not acquired. This cannot be a sound legal construction in that even acquisition below the prescribed percentage could parallel unfair treatment. ${ }^{93}$

\section{Comments}

The proposed exemptions should not be seen as exhaustive; thus these proposed exemptions are open to additional contributions. These exemptions are meant to indicate circumstances where it would be inapposite for the takeover rules to apply. Therefore, the exemptions are meant to fill the lacunae in the current regime. Although, section 119(6) seems to cover many situations by providing the Panel with wide authority to exempt some affected transactions, it remains uncertain who or which transaction in particular could be exempt from complying with the takeover rules. This creates uncertainty in a system which should hinge on precise and clear rules. It is globally accepted that business laws should be founded on clear and accessible laws. ${ }^{94}$ The regime of offers, in particular, must be clear and should provide the potential offeror and affected parties with sufficient information regarding exemptions.

\section{$5 \quad$ PROVISIONS ON LEEWAY WHERE CONTROL WILL BE ATTAINED}

The provisions contained in section 7 of the Companies Act sets out the aim this statute intends to achieve. It is submitted that the aim of the Act is to promote the development of companies within all sectors of the economy, and encourage active participation in economic organisation, management and productivity. ${ }^{95}$ The purpose is also to create optimum conditions for the aggregation of capital for productive purposes, and for the investment of that

\footnotetext{
92 S 60 and S 61(10) of the Companies Act 71 of 2008. The Companies Act empowers companies to adopt resolutions using electronic devices.

93 For instance, if a party acquires $19 \%$ of the voting securities of a regulated company, it could be argued that the acquirer has treated the rest of shareholders unfairly because the acquirer has not extended the same offer to the remaining security holders.

94 See Cassim 201022 SA Merc LJ 157.

$95 \mathrm{~S} 7(\mathrm{f})$ of the Companies Act 71 of 2008.
} 
capital in enterprises and the spreading of economic risk. ${ }^{96}$ The Act also intends to balance the rights and obligations of shareholders and directors within companies. ${ }^{97}$ It is overt from the provisions stated above that the Companies Act encourages shareholders and directors to actively participate in company affairs, and moreover encourages the creation of optimum conditions for the aggregation of capital for company growth.

The foundation of this statute is based on the idea that every stakeholder must be inspired to participate in company affairs to ensure growth and optimum investment of capital. This means that all shareholders must engage and play a part in acquisitions, organisation and transformation of the company. The statute particularly encourages shareholders to participate in economic organisation; presumably this will include economic reorganisation. In organising the capital of the company, it is fundamental that the interest of all stakeholders must be protected. ${ }^{98}$ Although, one part of organising the company in acquisitions is to provide minority shareholders with the liberty to elect to remain in the offeree company, or exit the company by compelling the offeror to acquire their securities, a few more options are needed. ${ }^{99}$ These options will offer a variety of methodologies as alternatives to the enforcement of mandatory offers. There must be a shift from providing the minority with only the option to remain or exit the company. The need for a shift will be consistent with the purpose of the Companies Act, which encourages economic growth and shareholder participation. This means that shareholders should be offered wide powers to participate in the reformation of the entity. Minorities must therefore be encouraged to actively participate in reorganisation or decision-making, as far as acquisitions are concerned. This development can be helpful in easing the cost of takeovers, and can also provide shareholders with feasible alternatives.

\section{Converting minority securities into debentures or preference shares}

This option should be made available to minorities in acquisition. This option will make acquisitions less expensive and will also provide minorities with adequate protection. The minorities must be provided with an option to have their securities converted to debentures or preference shares. ${ }^{100}$ The minorities must adopt the resolution to convert their securities by passing a special resolution. It must be noted that only those who would be affected and who have demanded that mandatory offers be made, should participate in the vote. ${ }^{101}$ This option should be made available to the company if it appears that the offeror may have difficulties to observe the takeover rules. However, there is a clear risk of the company failing the liquidity and the

\footnotetext{
$\mathrm{S} 7(\mathrm{~g})$ of the Companies Act 71 of 2008

S 7(i) of the Companies Act 71 of 2008.

Pretorius "The Future of South African Company Law" 200412 Juta's Business Law 66.

S 123 of the Companies Act 71 of 2008.

100 The creation of debt instruments has to comply with s 43(2)(a) and s 43(3) of the Companies Act 71 of 2008.

101 S 37(3) of the Companies Act 71 of 2008.
} 
solvency tests. ${ }^{102}$ This means that the company actually creates a debt which will have to be settled in the future, and an annual expense which comes in the form of interest payable. It stands to reason that the company ought to pass the liquidity and solvency test before the approval of the conversion, ${ }^{103}$ and have the proposal endorsed by affected parties, including the board of directors. It follows that every remaining security holder of the company should approve this change or resolution by a vote. The proposed scheme of arrangement must be adopted by a special resolution. This requirement is coherent with the provisions and the rules of fundamental transactions. ${ }^{104}$ This should be so, because the security holders' interests will be affected and, moreover, because of the amendment to equity capital, and the creation of a debt. Therefore, conversion of minority shares to debentures or preference shares, and the distribution to the remaining shareholders must comply with the rules of the scheme of arrangement, since such an arrangement gives rise to a fundamental transaction.

Even so, there will be some incentive to all parties concerned. The advantage of such an approach is that minorities become creditors and will receive income in the form of interest until the debt is settled. By the same token the equity capital of the company has to be adjusted due to the need to keep intact the pool of authorised issued shares and to provide incentive to the remaining shareholders. The number of shares which were converted to debentures must then be transferred proportionally to the remaining shareholder. A schematic structure can be provided as follows:

Figure 1

\begin{tabular}{|c|c|c|c|c|c|c|}
\hline $\begin{array}{l}\text { Equity } \\
\text { Structure } \\
\text { before }\end{array}$ & & & $\begin{array}{l}\text { Equity } \\
\text { Structure } \\
\text { After }\end{array}$ & & & \\
\hline Shareholders & share & percentage & Shareholders & shares & percentage & $\begin{array}{c}\text { Capitalised } \\
\text { Shares }\end{array}$ \\
\hline $\begin{array}{l}\text { Group A } \\
\text { Shareholders }\end{array}$ & 28700 & $19,6 \%$ & $\begin{array}{l}\text { A } \\
\text { Shareholders }\end{array}$ & 32592 & $22 \%$ & 3892 \\
\hline $\begin{array}{l}\text { Group B } \\
\text { Shareholders }\end{array}$ & 29130 & $20 \%$ & $\begin{array}{l}\text { B } \\
\text { Shareholders }\end{array}$ & 34221 & $23 \%$ & 4086 \\
\hline $\begin{array}{l}\text { Group C } \\
\text { Selling }\end{array}$ & 25830 & $17,6 \%$ & & 29332 & $20 \%$ & 3502 \\
\hline $\begin{array}{l}\text { Shareholders } \\
\text { Minority }\end{array}$ & 51230 & $35 \%$ & $\begin{array}{l}\text { Offeror } \\
\text { transferred to }\end{array}$ & 51230 & $35 \%$ & 0 \\
\hline shareholders & 11480 & $7,8 \%$ & $A, B \& C$ & - & - & 0 \\
\hline
\end{tabular}

102 Wainer provides a passage of what the term "liquidity and solvency tests" entails in the Companies Act; see particularly Wainer "The New Companies Act: Peculiarities and Anomalies" 2009126 SALJ 806 806-809.

${ }^{103} \mathrm{~S} 4$ of the Companies Act 71 of 2008.

104 See s 36(2), s 36(3), s 114 and s 115 of the Companies Act 71 of 2008. See further Latsky "The Fundamental Transactions Under the Companies Act: A Report Back from Practice After the First Few Years" 2014 Stell LR 361.

105 Chapter 5 of the Companies Act 71 of 2008. 


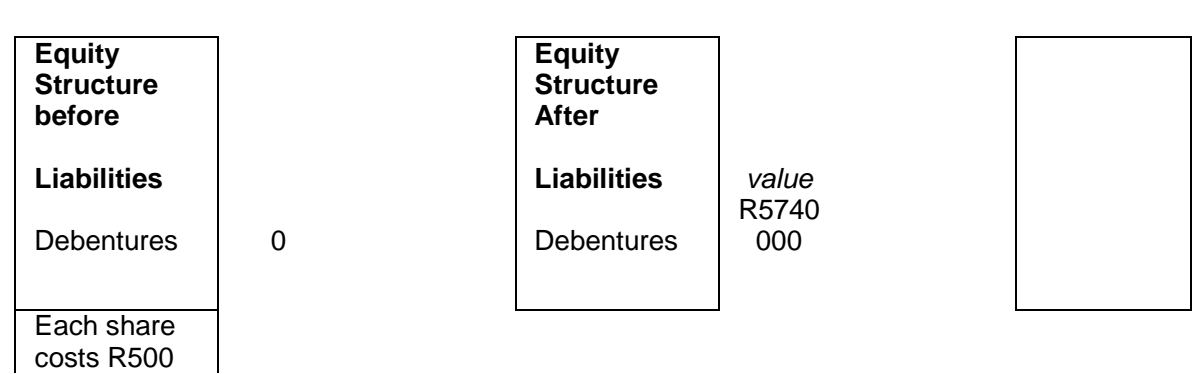

It must be noted that the shareholding of the company is wide-spread in this situation, which is a situation that gives the offeror effective control. It should not matter even where the offeror attain more than $50 \%$ of the voting securities, thus gaining de facto control, as long as the affected parties have agreed to the conversion the same benefits will be procured.

It is apparent that all parties concerned will benefit from such an arrangement. It must be noted that this approach will work only if the number of minorities is not large (thus, no more than $10 \%$ of securities must be converted), because the company must remain liquid and solvent after the rearrangement. The remaining shareholders will receive bonus shares, which will result in their share capital increasing. A clear advantage is that minorities will not be trapped in a company in which control has changed, and they will accrue the rights provided to creditors. ${ }^{106}$ A further advantage is that minorities will receive interest from their investment until the debt is settled, which is an occurrence that will not transpire if minority securities where bought instantly. In light of the above, distribution in the form of debt creation on behalf of the company must comply with section 46 of the Companies Act 2008, while capitalisation of shares must comply with section 47. There are obvious benefits for the offeror also; the offeror will not have to bear the onerous responsibility of making offers for minority shares. Therefore, acquisition of securities above the prescribed percentage will become less costly, and investors who will otherwise be put off by takeovers will no longer perceive the rules as a hindrance.

\section{The company buys minority securities}

In takeovers, companies should be allowed to acquire minority securities if the offeror has attained a large parcel of the company's share stock, and the only shareholders left in the company are the offeror and the minorities. Where there are a number of shareholders still left in the company, buybacks must be passed by a special resolution adopted by affected parties (that is, the existing shareholders). This should be so, because this approach might limit the distribution of dividends. This approach must comply with section 46, 114 and 115 of the Companies Act, which regulates buy-backs. It follows then that the board must authorise repurchases or buybacks. A number of advantages which buy-backs offer are highlighted by

106 Singer NO $v$ The Master 1996 (2) SA 133 (A); and Standard Bank of South Africa Ltd v Townsend 1997 (3) SA 41 (W): the courts discussed how payments to creditors should be made, taking into account the proper order of preference. See further Evans "Preferential Treatment of Employee Creditors in Insolvency Law" 200416 SA Merc LJ 458. The author discusses the order of preference with regard to insolvent companies. 
writers elsewhere. ${ }^{107}$ It is overt that the regime of takeovers may benefit from the inclusion of buy-backs in one of its core provisions.

In former years buy-backs were regulated under the ambit of capital maintenance rules, and recently the methods of liquidity and solvency test were introduced to regulate buy-backs. ${ }^{108}$ In the current statute, buy-backs are considered distributions, and as such the liquidity and solvency tests must be satisfied immediately after any distributions. The term "distributions" includes a whole host of transactions, particularly deliveries of company assets or property to shareholders. ${ }^{109}$ The board of a company may make distributions if it is satisfied that the company will be liquid and solvent after such distributions. ${ }^{110}$ This means that immediately after the distribution the company must be able to settle its debts as they fall due, and its assets fairly valued must exceed its liabilities. If this requirement is satisfied, then minority securities should be repurchased by the company. If a resolution is passed empowering the company to repurchase minority securities, the offeror will, therefore, not be compelled to make offers for minority securities. Should other shareholders be involved, the offeror then has to convince those shareholders that there is an incentive in the company repurchasing the minority securities. Perhaps, the offeror might indicate that in the near future it will inject substantial amounts of money into the enterprise, which will result in considerable profits and benefit the remaining shareholders financially. Alternatively, the remaining shareholders may agree to a capitalisation issue similar to the above option. The affected shareholders will then have to adopt a special resolution to sanction the repurchase. This implies that the minorities and the remaining shareholders have to adopt the resolution in separate ballots.

107 Cassim The Law of Business Structures (2013) 193, the authors list the advantages of buybacks as follows - (i) Share repurchases can be utilised to buy out dissident shareholders. (ii) Share repurchase enable a company to return surplus funds to shareholders who can then make other more profitable investments. (iii) Share repurchase can be used to maintain or achieve what is perceived to be a desirable debt-equity ratio. (iv) Where a company has a number of shareholders with small shareholdings, the administrative overheads that this causes can be reduced by the company buying out these "odd-lots" without incurring any material cost. (v) A share repurchase assists companies engaging in takeovers and mergers by enabling them to take shares off the market to be reissued as consideration in takeovers and mergers without dramatically increasing the company's issued shares. (vi) A share repurchase provides a means to avert a hostile takeover. (vii) Repurchase assists management in a buy-out of control of their company by reducing (at company expenses) the number of shares that have to be acquired to gain control of the company.

${ }^{108}$ An account of the emergence and the demise of the concept of capital maintenance and the introduction of the liquidity and solvency tests have been thoroughly canvassed by writers: see Cassim "The Reform of Company Law and the Capital Maintenance Concert" 2005122 SALJ 283 284; Wainer "The Companies Act Changes - Problems and Doubts" 2001118 SALJ 133-139; and Van der Linde "The Regulation of Share Capital and Shareholder Contributions in the Companies Bill 2008" 2009 TSAR 39-57.

109 See the definition of distributions contained in s 1 of the Companies Act 71 of 2008.

110 S 46(1)(b) of the Companies Act 71 of 2008. 


\section{Restricting the offeror from participating in a resolution which could prejudice minorities}

This option should be employed where the offeror has acquired control of the company, but has failed to comply fully with the mandatory offer rule. This means that the offeror must be barred from voting on resolutions relating to plans meant to transform the company or relating to securities of the remaining shareholders. Thus, only the remaining shareholders must consider plans to transform the company and matters relating to their rights and securities.

The restriction must happen where the abovementioned options were unavailable to the company; nevertheless, the offeror insisted in acquiring securities above the prescribed percentage. In a true sense this should be seen as a sanction rather than an alternative to mandatory offers. The offeror (and the parties acting in concert if indeed they were so acting) must have the rights associated with its securities suspended, until it fully complies with the rules. The offeror should lose some of the rights relating to securities, especially the voting rights. ${ }^{111}$ If it appears that the offeror will completely fail to comply with the rules, the right to vote in resolutions that are likely to prejudice the remaining shareholders must be suspended for a period of ten years. The offeror should therefore be allowed to vote only on resolutions that have no bearing on the rights and interests of the remaining shareholders. However, the offeror should retain some of the rights associated with its shareholding, such as the right to receive declared dividends. The offeror should furthermore be allowed to propose resolutions for consideration in shareholder meetings, but must not vote on any resolution affecting rights and interests of other shareholders. This means that the shareholder should not be able to elect directors, nor vote on resolutions pertaining to disposal of property, nor vote on resolutions pertaining to rearrangement of equity capital, unless its capital will be adversely affected. Restrictive measures should be put in place to protect minorities against possible abuse. ${ }^{12}$ In actual fact, after the offeror has attained control, the company will basically be controlled by minorities. Where minorities engage in acts that are most likely going to damage the interest of the offeror, the offeror must be able to approach the Panel for relief or have the court set aside the adopted resolution. Moreover, the offeror must be allowed to dispose of its securities any time after acquisition. Where the offeror has purchased the securities at a premium, the offeror must be liable to minorities for the premium paid, in that the premium embodies damage minorities have suffered. ${ }^{113}$

This option should not be seen as an instrument to deter offerors, but as a mechanism to protect minorities. In this respect, an offeror that intends to invest in an enterprise for legitimate reasons could still acquire securities in

\footnotetext{
111 This is a sanction used in Germany. However, the German sanction is far-reaching because the offeror loses the right to vote in company resolutions completely and the rights to receive dividends is also forfeited; see Ziemons, Schlotter and Hilmer "Takeover Bids in Germany" in Van Gerven (ed) Common Legal Framework for Takeover Bids in Europe (2008) 172.

112 See, eg, Luiz 201022 SA Merc LJ 443.

113 Haslam v Sefalana Employee Benefits Organisation supra 275.
} 
regulated companies as long as the offeror trusts that its investment will reap rewards without its engagement in certain votes. Thus, the investor may invest in a regulated company without having to contend with the reality of making offers for securities the investor does not desire to acquire or have the means to acquire.

\section{CONCLUSION}

The lack of precise exemptions in the system of mandatory offers is hard to reconcile with the purpose of the Companies Act, which seems to endorse economic activity. Mandatory offers must not be used mainly as a deterrent, but as a mechanism to protect shareholders. Thus, legitimate offerors should not be deterred by restrictive rules. This article has highlighted a number of ways in which minorities may be protected, while at the same time providing leeway for honest offerors. It is correct to aver that there are company looters, and their aim is to exploit the opportunities provided by takeover. ${ }^{114}$ However, takeover rules should not be overly concerned with possible looters and corporate bullies at the expense of legitimate offerors. Therefore, provisions which will deter possible looters and corporate bullies must be fashioned, while at the same time providing genuine offerors with opportunities to acquire securities in regulated companies.

This exposition has provided an account of possible exemptions that may be implemented to supplement the system of mandatory offers. It also provides reasons why the enforcement of mandatory offers will be unsuitable in certain situations. It has been clearly outlined that it will be inapt to enforce mandatory offers during business rescue. The commencement of business rescue could lead the company into issuing new securities to raise capital. Should it then be expected that, if $60 \%$ of the shareholders form the minority, the offeror must acquire a further $60 \%$ of the securities. This could be an unreasonably costly exercise for business rescue. It is clear that it would be inapt to enforce mandatory offers under such situations. Where the company unanimously adopts a fundamental transaction with little opposition, it stands to reason that the shareholders who adopted such a resolution would have consented to the change of control of the company. Thus, the minorities who voted in favour of the transaction, or those who never voted, cannot demand that offers be made for their securities. Only shareholders who rejected the transaction, or those who have indicated that they will exercise the right to mandatory offers must have locus standi to demand that their securities be purchased. Thereupon the company may repurchase the shares or, with consent of affected parties, convert the shares into debentures or preference shares. Where these options are unavailable, mandatory offers must be made.

It could be compellingly argued that this article has underplayed the need for proportional treatment of security holders in acquisitions. On the contrary, the idea of unfair treatment derives prominence where controlling power is gained and the possibility of abuse is material. The law implies that abuse or bullying can only occur where there is a transference or consolidation of

114 Spinnaker Investments (Pty) Ltd v Tongaat Group Ltd supra. 
company control. ${ }^{115}$ It is overt that, where a party acquires securities under the prescribed percentage and does not extend the offer to minorities, it cannot be said that such conduct amounts to unfair treatment. Only in situations where the offeror has gained control could we assert that a case of unfair treatment could be argued. The offeror has to practice fair treatment where imperilment is likely to befall minorities.

The current and previous regimes of mandatory offers fail to provide clear and precise exemption. This state of affairs can make it difficult for bidders or offerors to conduct the business of acquisition with utmost confidentiality and confidence. It is not clear whether the Panel could exempt the offeror in all proposed exemptions provided above. Indeed, some may vigorously criticize the extent of the proposed exemptions, citing that the exemptions and leeway proposed are so wide that they devalue the whole system of mandatory offers. I suggest not, perhaps they should pay due regard to the mischief this system is projected to curtail. Maybe they are protagonists of the mandatory offer system itself, and not necessarily advocates of minority protection, hence any mechanic that seems to strike deep into the heart of mandatory offers seems problematic. It is significant to identify what drives policymakers to apply laws to aid order relationships between various parties rather than leaving them to their own devices. Accordingly, the appreciation of the basis that informs the policy of mandatory offers is critical. It is trite that the mandatory offers rule was envisioned to protect the vulnerable against unfair treatment and abuse; thus this exposition provides a clear distinction between perilous and non-perilous acquisitions. This provides credence to a regime that appears to be sweeping, superficial and superfluous.

115 Sefalana Employee Benefits Organisation v Haslam supra. 